\title{
Effects of Tibolone on Bone Mass in Postmenopausal Women
}

\author{
Postmenopozal Kadınlarda Tibolonun Kemik Kütlesi Üzerindeki Etkisi
}

\author{
Snezana Maric KREJOVIC, ${ }^{1}$ Aleksandar ZIVANOVIC, ${ }^{2}$ Bajram HASANI, ${ }^{3}$ Tatjana ILLE, ${ }^{4}$ Andrea GLISIC ${ }^{5}$ \\ ${ }^{1}$ Department of Obstetrics and Gynecology, General Hospital Uzice-Health Center Arilje, Serbia; \\ ${ }^{2}$ Department of Obstetrics and Gynecology, Faculty of Medicine, University of Kragujevac, Serbia; \\ ${ }^{3}$ Department of Pediatrics, Health Center Bujanovac, Toljska bb, Serbia; \\ ${ }^{4}$ Department of Biostatistics, Faculty of Medicine, University of Belgrade, Serbia; \\ ${ }^{5}$ Department of Obstetrics and Gynecology, Institute for Gynecology and Obstetrics, Clinical Center of Serbia, University of Belgrade, Serbia
}

Objectives: We aimed to investigate the effects and tolerability of tibolone treatment in women with postmenopausal osteoporosis.

Patients and methods: Patients received tibolone tablets orally once a day after receiving strict instructions. All patients received calcium supplementation with $500 \mathrm{mg}$ of active calcium, and $400 \mathrm{IU}$ of vitamin D. For the purpose of this study, 93 women who received tibolone for two years were examined. They comprised the study group. The second group included 33 women with osteoporosis who received only a supplement of $500 \mathrm{mg}$ of active calcium and 400 IU vitamin D. The third group (control) was composed of 42 women with osteoporosis who took no medication if advised to do so. Bone mineral density was measured at the lumbar spine, and measurements were performed prior to treatment, after one year, and after two years of treatment using the dual energy X-ray absorptiometry method. The bone mineral density was examined in the group of 33 women taking calcium and vitamin $\mathrm{D}$ and in the group taking no medication.

Results: A $4.9 \%$ improvement in bone mass was registered after a year of treatment with tibolone, and there was a $7.5 \%$ improvement after two years. In patients receiving calcium and vitamin D, a significant increase in bone mass of $2.9 \%$ occurred as well after a year, but the values returned to the baseline level after the second year. In patients without any treatment, the bone mass decreased by $0.6 \%$ after a year and by $0.9 \%$ after the second year.

Conclusion: Our two-year study of the efficacy and tolerability of tibolone in women with osteoporosis confirmed that tibolone significantly increases vertebral bone mass with good tolerability. This finding indirectly implies that the risk of both vertebral and non-vertebral fractures is also significantly reduced.

Key words: Osteoporosis; postmenopause; tibolone.
Amaç: Postmenopozal osteoprozlu kadınlarda tibolon tedavisinin etkilerini ve tolerabilitesini araştırmayı amaçladık.

Hastalar ve yöntemler: Sıkı talimatlar almalarının ardından, hastalar oral yolla günde bir defa tibolon tabletleri aldı. Tüm hastalar $500 \mathrm{mg}$ aktif kalsiyum ve 400 IU D vitamini ile kalsiyum takviyesi aldı. Çalışmanın amacı uyarınca, iki yıl boyunca tibolon tedavisi gören 93 kadın incelendi. Bu hastalar çalışma grubunu oluşturdu. İkinci grup yalnızca $500 \mathrm{mg}$ aktif kalsiyum ve 400 IU D vitamininden oluşan bir takviye alan osteoporozlu 33 kadını içermekteydi. Üçüncü grup (kontrol grubu) tavsiye verilmesi durumunda hiçbir ilaç almamış olan 42 kadından oluşmaktaydı. Kemik mineral yoğunluğu lomber omurgada ölçüldü ve ölçümler dual enerjili $X$ ışını absorbsiyometrisi yöntemiyle tedaviden önce ve bir ve iki yıllık tedavinin ardından gerçekleştirildi. Kemik mineral yoğunluğu kalsiyum ve D vitamini alan 33 kadından oluşan grupta ve hiç ilaç almayan grupta incelendi.

Bulgular: Tibolonla uygulanan bir yıllık tedavinin ardından kemik kütlesinde \%4.9'luk bir iyileşme kaydedildi ve iki yıl sonra \%7.5'lik bir iyileşme mevcuttu. Kalsiyum ve D vitamini alan hastalarda bir yıl sonra kemik kütlesinde \%2.9'luk anlamlı bir artış meydana geldi ancak değerler ikinci yılın ardından başlangıç seviyesine geri döndü. Herhangi bir tedavi almayan hastalarda, kemik kütlesinde bir yıl sonra \%0.6, ikinci yılın ardından ise \%0.9'luk azalma meydana geldi.

Sonuç: Osteoporozlu kadınlar üzerinde tibolonun etkinliği ve tolerabilitesi konusunda yürüttüğümüz iki yıllık çalışmamız tibolonun iyi bir tolerabilite ile vertebral kemik kütlesinde anlamlı ölçüde artış sağladığını doğruladı. Bu bulgu dolaylı olarak, hem vertebral hem de non-vertebral kırık riskinin de anlamlı ölçüde azaldığı anlamına gelmektedir.

Anahtar sözcükler: Osteoporoz; postmenopozal; tibolon.

\footnotetext{
Received: October 16, 2010 Accepted: May 10, 2011
}

Correspondence: Snezana Maric Krejovic, M.D. Health Center Arilje Women's Health Care Service Str. Vojvode Stepe 8. 31230 Arilje, Serbia.

Tel: +38131/896-501 e-mail: snezana.krejovic@gmail.com

@2011 Turkish League Against Rheumatism. All rights reserved. 
Osteoporosis, a systemic disease of bones, is a serious health and socio-economic problem because of the consequence of broken bones. It is believed that $10 \%$ of the world's population suffers from osteoporosis, and it affects mostly postmenopausal women (postmenopausal osteoporosis). This disorder is especially critical due to the resulting fractures which commonly occur in one out of two women and one out of seven men aged 50 and over. The most common fractures occur at the spine, hip and distal part of the forearm, but other fractures also occur which involve the ribs and upper arms. It is also possible to find fractures in the lower legs and pelvic bones, The most severe are the hip fractures with a lethal outcome in one out of five affected patients in the course of the first year following the fracture. ${ }^{[1,2]}$

Although osteoporosis is a complex, generalized skeletal disorder that weakens the bones and increases the risk of fractures, ${ }^{[3]}$ in everyday practice, osteoporosis is mainly defined through a single dimension the bone mass (quantity) who is responsible for $60-80 \%$ of bone strength.

A consequence of these disorders is fractures, mostly of the dorsal part of the spine, hip and the distal part of the forearm. Risk of spine fractures in women is $20 \%$, for hip fracture $18 \%$, and the fractured distal part of forearm $15 \% .{ }^{[4]}$

The most serious consequence of osteoporosis is a hip fracture, which always requires hospitalization. There is a high mortality rate in the first year after hip fracture of about $24 \%$, an increase of $12-20 \%$ mortality compared to women of similar age without fractures of the hip. Half of the patients become dependent on other people's help, and about one-third become completely immobile. ${ }^{[5,6]}$

The number of hip fractures in the world in 1990 was 1.7 million, and it is expected that the number by 2050 will be 6.3 million as the incidence of hip fractures increases with age. Costs for hip fractures in 2002 were 48 billion dollars, and this will have a manifold increase in the coming years. ${ }^{[7,8]}$

To prevent an unfavorable course in the development of osteoporosis and fractures, it is necessary to identify persons, especially women, at high risk for fracture and determine the appropriate therapeutic interventions to prevent them. In turn, this can reduce major health, social, and economic effects. However, more than 50\% of the women with osteoporosis are now undiagnosed because it does not provide symptoms and signs which are easily seen in the beginning. A fracture is often the first clear evidence of osteoporosis. In order to identify individuals in a timely manner who are at risk for fractures, we should actively look for them by considering the risk factors for osteoporosis and fracture, which are sometimes more important than the resulting osteodensitometry findings of reduced bone density and bone strength who have a share of $60-80 \%$. Bone density is a recognized risk factor for fracture [a reduction in bone density of 1 standard deviation (SD) increases the risk of fracture of 2.2 to 2.4 times], but it is not the only risk factor involved. People who do not have densitometric osteoporosis and who have normal or reduced bone mass (osteopenia) can get a fracture. Conversely, people with a considerable bone density disorder might never suffer a fracture. ${ }^{[9,10]}$

Until a better method of diagnosing osteoporosis and anticipating possible fractures is found, the World Health Organization (WHO) has recommended bone mass assessment [bone mineral density (BMD)] by dual energy X-ray absorptiometry (DXA). Bone mineral density is expressed as SD where one SD equals $10 \%$ of bone mass. This method is simple, precise, fast, cheap, and safe for patients, and may be repeated while monitoring the effects of treatment.

The goal of osteoporosis treatment is to prevent bone loss, increase bone density, reduce bone turnover, and improve bone mineralization, all of which should increase bone strength and prevent fractures. A good osteoporosis treatment agent should have all these features and also be safe and well tolerated by patients who would have to use it for a number of years.

Tibolone is a synthetic steroid that has estrogenic, androgenic, and, progestagenic properties. It has been used primarily for the prevention of postmenopausal osteoporosis and treatment of climacteric symptoms. Although tibolone itself is not biologically active, its metabolites ( 3 beta $\mathrm{OH}$-tibolone, 3 alfa $\mathrm{OH}$-tibolone, and the delta-4-isomer of tibolone) have an effect on various tissues. Many clinical trials have shown that tibolone prevents bone loss and maintains skeletal integrity in postmenopausal women. ${ }^{[1-14]}$

This study was aimed to show the effects of tibolone in bone mass in postmenopausal women.

\section{PATIENTS AND METHODS}

A long-term, prospective study of the efficacy and tolerability of tibolone in patients with osteoporosis was conducted at the Medical Center Uzice. A special questionnaire was designed which included basic data 
for each patient, personal and family medical history, and lifestyle information. Body mass and height were measured for each patient at the baseline as well as BMD values at the lumbar spine using the DXA method (Lunar-DPX-L densiometer). Patients received tibolone tablets once a day orally, and instructions were strictly following. All patients received calcium supplementation with $500 \mathrm{mg}$ of active calcium (Ca), and $400 \mathrm{IU}$ of vitamin D. For the purpose of this study, the first group (or study group) examined was composed of 93 women (mean age 50.7 \pm 9.1 years; range 33 to 61 years) who received tibolone for two years. The second group included 33 women (mean age $51.2 \pm 4.13$ years; range 35 to 55 years) with osteoporosis who received only a supplement (500 $\mathrm{mg}$ of active calcium and 400 IU vitamin D). The third (control) group consisted of 42 women (mean age $51.7 \pm 16.5$ years; range 35 to 59 years) with osteoporosis who took no medication even when advised to do so.

The diagnosis of osteoporosis is based on:

- A bone mineral density T-score $\geq-2.5 \mathrm{SD}$ with or without risk factors (WHO recommends T-score $\geq-2.5$ $\mathrm{SD}$ for diagnosis of osteoporosis);

- A bone mineral density T-score $=-2.0 \mathrm{SD}$ with at least one recognized risk factor for osteoporotic fracture [family history of osteoporosis or spontaneous fractures, early menopause, gonadal failure, prolonged immobilization, administration of steroids for over six months, malignancies, decrease in body height, or low body mass index (BMI)];

- A new fracture and/or medical history of a fracture occurring spontaneously or with a minimal trauma in patients over 40 years of age.

Each participant in the study was aware of the purpose and methods of clinical research. It was explained that these were routine clinical tests and controls in postmenopausal women. The ethics committee of the Medical Center Uzice (No: 0303/4942; 01.12.2009) approved the clinical research and the patients' written consent was obtained.

\section{Statistical analysis}

The following descriptive statistics were used in this study: arithmetic mean, SD, median (minimummaximum). Differences between the groups were assessed by an Analysis of Variance (ANOVA) test, the Kruskal-Wallis test and the Mann-Whitney U-test. A general linear model, Bonferroni test, Friedman test and Wilcoxon test were used to test change in BMD and the $\mathrm{T}$ score at baseline and after the first and second year. $P$ values less than 0.05 were considered statistically significant.

\section{RESULTS}

All of the 93 women in the tibolone study group were in menopause which began at the mean age of $45.3 \pm 8.7$ (between 33 and 61) and lasted 3.1 \pm 1.0 (1-5) years. Early menopause (between 33 and 45) occurred in 45 (48.38\%) patients with 22 of those due to surgery or illness. In seven additional women, menopause started after gynecological surgery performed between the age of 45 and 61. Fourteen (15.05\%) patients reported a decrease in body height while the same number of patients had decreased BMI.

The second group of the 33 women comprised of those who were taking only calcium and vitamin $\mathrm{D}$ started menopause at the age of $40.4 \pm 5.2$ (between 36 and 55), and it lasted for $4.8 \pm 1.8(0.5-7)$ years. Early menopause started between the age of 36 and 45 in 20 patients (60.60\%) with five of those due to surgery. Three women started menopause between the age of 45 and 55 due to surgery. Five (15.15\%) patients reported a decrease in body height while seven (21.21\%) patients had a decreased BMI.

The third (control) group of 42 women did not take any therapy. Menopause started at the age of $47.2 \pm 5.2$ (between the age of 32 and 59) and lasted for $6.9 \pm 2.0$ (1-8) years. Early menopause started between the age of 32 and 45 in 18 patients (42.85\%) with three of those due to surgery. One (2.38\%) patient reported a decrease in body height while seven (16.66\%) patients had a decreased BMI.

The worst results for bone mass were found in the women taking tibolone, with an average T-score of $-2.57 \mathrm{SD}$. This is compatible with a densitometry diagnosis of osteoporosis. Patients in the other two groups had similar T-scores which were equivalent to a densitometry diagnosis of osteopenia (according to the WHO definition of a T-score between -1 and -2.5 SD). Patients receiving calcium and vitamin $\mathrm{D}$ had -1.86 SD while those not taking any therapy had a T-score of -2.02 SD.

The influence of therapy on BMD was tested with the General Linear Model for Repeated Measures. Test results showed that there was a statistically significant difference between these three measurements $(\mathrm{F}=2.458$; $\mathrm{p}<0.001)$, and there is a statistically significant influence of group membership $(\mathrm{F}=1.789 ; \mathrm{p}=0.014)$. Results 


\begin{tabular}{|c|c|c|c|c|c|c|}
\hline \multirow[t]{3}{*}{ Groups } & \multicolumn{3}{|c|}{ Bone mineral density } & \multicolumn{3}{|c|}{ Multiple comparison (Bonferroni) } \\
\hline & Baseline & 1 year & 2 years & Baseline vs. 1 year & Baseline vs. 2 years & 1 year vs. 2 years \\
\hline & Mean \pm SD & Mean \pm SD & Mean \pm SD & $p$ & $p$ & $p$ \\
\hline Tibolone $(n=93)$ & $0.86 \pm 0.11$ & $0.91 \pm 0.14$ & $0.96 \pm 0.13$ & $<0.001$ & $<0.001$ & $<0.001$ \\
\hline $\mathrm{Ca}+\mathrm{VitD}(\mathrm{n}=33)$ & $0.97 \pm 0.11$ & $1.00 \pm 0.13$ & $0.97 \pm 0.24$ & $=0.036$ & $=0.912$ & $=0.068$ \\
\hline Control $(n=42)$ & $0.99 \pm 0.20$ & $0.93 \pm 0.17$ & $0.92 \pm 0.18$ & $=0.092$ & $=0.086$ & $=0.672$ \\
\hline
\end{tabular}

of multiple comparisons between measurements conducted at baseline and after the first year and second year are shown in table 1.

We also tested the change in $\mathrm{T}$ score for all three groups. The results of the Friedman test showed that there was a statistically significant difference in $\mathrm{T}$ score at baseline and after the first and second year in the study group $\left(\mathrm{X}^{2}=16.133 ; \mathrm{p}<0.001\right)$ and in the second group $\left(\mathrm{X}^{2}=9.171 ; \mathrm{p}=0.038\right)$, but there was no statistically significant difference in the control group $\left(\mathrm{X}^{2}=4.128 ; \mathrm{p}=0.389\right)$. Descriptive statistics and test results are shown in table 2 .

Finally, we compared the BMD and T score between each group at baseline and after the first and second year. Test results are shown in table 3.

Graphs 1 and 2 show a significant increase of bone mass in patients treated with tibolone, despite these patients having the worst baseline bone mass. In the group of patients receiving calcium and vitamin D supplements, the bone mass increased after a year, but then returned to the baseline score after two years. In the control group, the bone mass decreased after the first year and continued to decrease after the second year, although the decrease was statistically insignificant (figure 1 and 2).

\section{DISCUSSION}

The results of a two-year oral administration of tibolone in women with osteoporosis demonstrated positive effects on the bone mass. The efficacy of tibolone in various forms of osteoporosis in both men and women of all age groups has been demonstrated in numerous published studies that included several thousands of patients. Fracture risk reduction was demonstrated for vertebral fractures, hip fractures, and non-vertebral fractures, and this effect was consistent for several years. In our

Table 2. T score in each group and test results

\begin{tabular}{|c|c|c|c|c|c|c|c|c|c|}
\hline \multirow[b]{3}{*}{ Groups } & \multicolumn{6}{|c|}{ T score } & \multicolumn{3}{|c|}{ Multiple comparisons (Wilcoxon) } \\
\hline & \multicolumn{2}{|c|}{ Baseline } & \multicolumn{2}{|c|}{1 year } & \multicolumn{2}{|c|}{2 years } & \multirow{2}{*}{$\begin{array}{c}\begin{array}{c}\text { Baseline vs. } \\
1 \text { year }\end{array} \\
p\end{array}$} & \multirow{2}{*}{$\begin{array}{c}\begin{array}{c}\text { Baseline vs. } \\
2 \text { years }\end{array} \\
p\end{array}$} & \multirow{2}{*}{$\begin{array}{c}1 \text { year vs } \\
2 \text { years } \\
p\end{array}$} \\
\hline & Mean \pm SD & Median & Mean \pm SD & Median & Mean \pm SD & Median & & & \\
\hline Tibolone $(n=93)$ & $-2.57 \pm 0.93$ & -2.51 & $-2.10 \pm 1.14$ & -2.07 & $-2.04 \pm 1.09$ & -1.99 & $<0.001$ & $<0.001$ & $=0.124$ \\
\hline $\mathrm{Ca}+\mathrm{VitD}(\mathrm{n}=33)$ & $-1.86 \pm 0.79$ & -1.90 & $-1.57 \pm 0.91$ & -1.61 & $-1.86 \pm 1.01$ & -1.94 & $=0.024$ & $=0.734$ & $=0.049$ \\
\hline Control $(n=42)$ & $-2.02 \pm 1.47$ & -1.98 & $-2.08 \pm 1.16$ & -2.14 & $-2.17 \pm 1.26$ & -2.24 & $=0.092$ & $=0.861$ & $=0.074$ \\
\hline
\end{tabular}

\begin{tabular}{|c|c|c|c|c|c|c|}
\hline \multirow{3}{*}{ Groups } & \multicolumn{3}{|c|}{ Bone mineral density ${ }^{*}$} & \multicolumn{3}{|c|}{$\mathrm{T}$ score $^{* *}$} \\
\hline & Baseline & 1 year & 2 years & Baseline & 1 year & 2 years \\
\hline & $p$ & $p$ & $p$ & $p$ & $p$ & $p$ \\
\hline All groups & $<0.001$ & $<0.001$ & $=0.036$ & $=0.482$ & $<0.01$ & $=0.297$ \\
\hline Tibolone vs. Ca+Vitamin D & $<0.001$ & $<0.001$ & $=0.017$ & $=0.408$ & $=0.001$ & $=0.766$ \\
\hline Tibolone vs. control & $<0.001$ & $<0.01$ & $=0.934$ & $=0.542$ & $=0.474$ & $=0.146$ \\
\hline $\mathrm{Ca}+$ Vitamin $\mathrm{D}$ vs. control & $=0.607$ & $=0.574$ & $=0.108$ & $=0.253$ & $=0.054$ & $=0.305$ \\
\hline
\end{tabular}




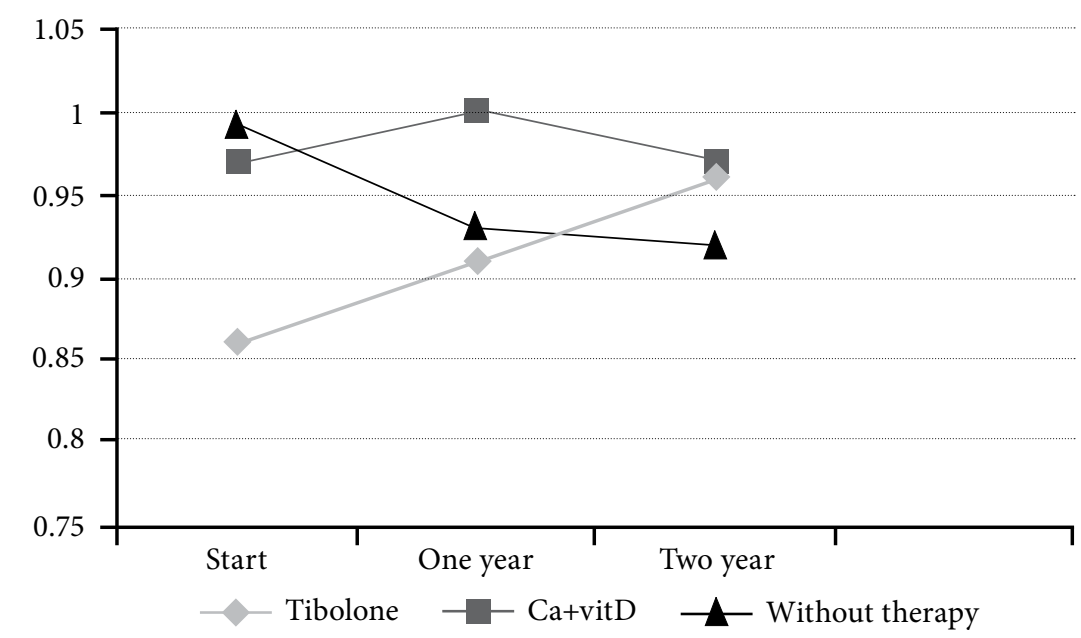

Figure 1. Bone mineral density in $\mathrm{gr} / \mathrm{m}^{2}$ at the beginning, after one, and after two years.

study on the effects of tibolone on bone mass, we established that after a year, the bone mass at the lumbar spine increased by $4.9 \%$, and by $7.5 \%$ after two years. This is in accordance with the data from the literature and demonstrates an increase of bone mass at the lumbar spine of between 4 and $5.8 \%$ in the first year of therapy. It is considered that the increase of bone mass occurs significantly faster during the first 12 months of treatment with tibolone. Further increase is slower with only an approximately $0.8 \%$ growth for every subsequent year. It was also established that a relatively small increase of bone mass significantly decreases the fracture risk. For example, an annual increase of lumbar bone mass by $4 \%$ decreases the vertebral fracture risk by $50 \%$ and non-vertebral fracture risk by $39 \%$.
Bone mass significantly increased in the group of patients on calcium and vitamin D supplements in the first year by $2.9 \%$, but in the second year it dropped back to the baseline. The only explanation for such a result was that substitution therapy had only a limited effect on bone mass, both in regard to quantity and time. All double-blind placebo controlled studies use calcium with vitamin $\mathrm{D}$ as a placebo as it has been demonstrated that their effects on bone mass and fractures were insignificant. On the other hand, there have been some studies on limited groups of patients (community-dwelling elderly people) demonstrating the positive effects of calcium and vitamin $\mathrm{D}$ on the reduction of vertebral fracture risk. ${ }^{[15]}$ Fracture risk in our group of patients after two years was supposed to be unchanged when compared with the baseline considering the unchanged bone mass. This implies

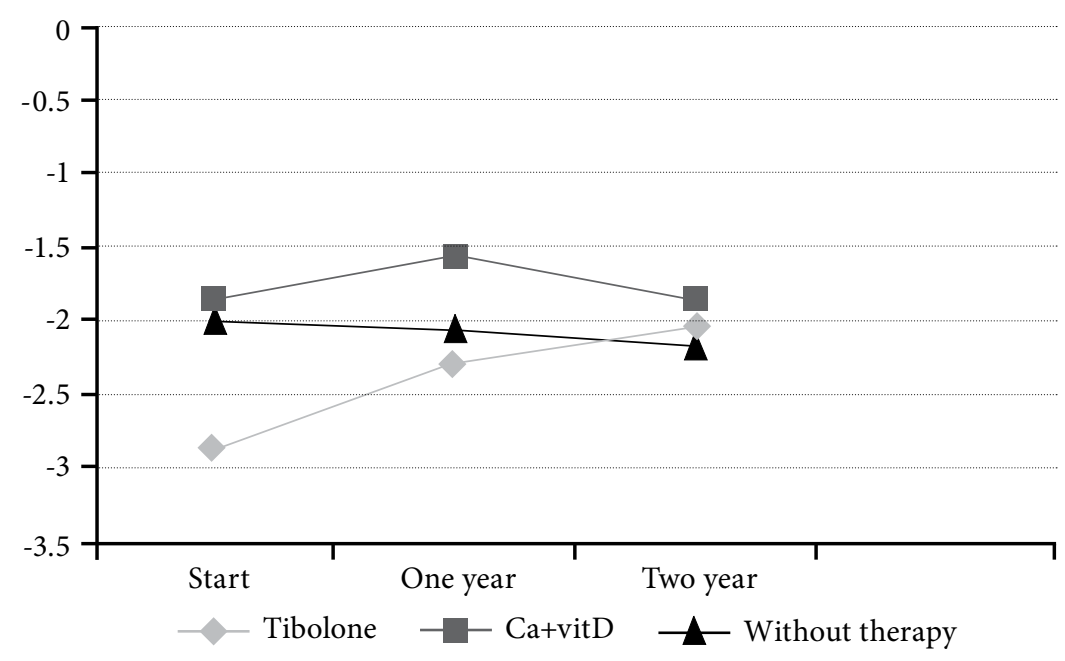

Figure 2. T score in standard deviation at beginning, after one, and after two years. 
that fracture risk in these women was four times higher compared to women with normal bone mass because the reduction of bone mass by 1 SD increases the fracture risk by 2.2 times. ${ }^{[16]}$

The control group included women with osteoporosis who did not take any medications, although they were advised to do so. The main reason for this was financial. During the first year they lost $0.6 \%$ of bone mass and $0.9 \%$ after the second year which was insignificant. In untreated, postmenopausal osteoporosis, the expected annual loss of bone mass is over $1 \%$. This relatively low bone mass loss was probably due to general prevention measures advised at examination (diet, activity, sunbathing, removing negative factors). The fracture risk in these women increased (considering the reduced bone mass) by $0.9 \%$. The fracture risk measured with densitometry at the beginning of this study increased by 4.2 times and increased after two years by approximately five times compared with women with normal densitometry results.

These results suggest that a two-year tibolone therapy treatment increased bone mass by $7.5 \%$ compared with patients taking calcium and vitamin $\mathrm{D}$ and by $8.4 \%$ compared with patients without therapy. This significantly reduced fracture risk, which is the main goal of osteoporosis therapy.

In conclusion, osteoporosis is a systemic skeletal disease characterized by low bone density and microarchitectural deterioration of bone and tissue leading to enhanced bone fracture risk. Prevention of osteoporosis should include all ages and genders without any assessment of individual risk factors. Our two-year treatment program involving the efficacy and tolerability of tibolone in women with osteoporosis confirmed that tibolone significantly increases vertebral bone mass with good tolerability. This finding indirectly implies that the risk of both vertebral and non-vertebral fractures is also significantly reduced.

\section{Declaration of conflicting interests}

The authors declared no conflicts of interest with respect to the authorship and/or publication of this article.

\section{Funding}

The authors received no financial support for the research and/or authorship of this article.

\section{REFERENCES}

1. Kanis JA, Johnell O, Oden A, Sembo I, Redlund-Johnell I, Dawson A, et al. Long-term risk of osteoporotic fracture in Malmö. Osteoporos Int 2000;11:669-74.

2. Dawson-Hughes B. Educational symposium: new perspective in the understanding and treatment of osteoporosis. March 6-9, 2002, Hawaii: 5th International symposium: clinical advances in osteoporosis. Honolulu, Hawaii: National Osteoporosis Foundation; 2002. p. 1.

3. Chesnut $\mathrm{CH}$ 3rd, Rosen CJ; Bone Quality Discussion Group. Reconsidering the effects of antiresorptive therapies in reducing osteoporotic fracture. J Bone Miner Res 2001;16:2163-72.

4. Grady D, Rubin SM, Petitti DB, Fox CS, Black D, Ettinger B, et al. Hormone therapy to prevent disease and prolong life in postmenopausal women. Ann Intern Med 1992;117:1016-37.

5. Leidig-Bruckner G, Minne HW, Schlaich C, Wagner G, Scheidt-Nave C, Bruckner T, et al. Clinical grading of spinal osteoporosis: quality of life components and spinal deformity in women with chronic low back pain and women with vertebral osteoporosis. J Bone Miner Res 1997;12:663-75.

6. Hawker GA. The epidemiology of osteoporosis. J Rheumatol Suppl 1996;45:2-5.

7. Chada HW. Factors that influence fracture resistance: current understanding. Aventis Symposium. IOF World Congress on Osteoporosis. May 14-18, 2004, Rio De Janeiro, Brazil: International Osteoporosis Foundation; 2004. p. 1-2.

8. Utian WH. Health beyond menopause. Satellite Symposium at IOF World Congress on osteoporosis. May 14-18, 2004, Rio de Janeiro, Brazil: International Osteoporosis Foundation; 2004. p. 4-6.

9. Siris SE. Bone Health Menopause: Assessing WHO is At Risk of Developing Osteoporosis. Satellite Symposium at IOF World Congress on Osteoporosis. May 14-18, 2004, Rio De Janeiro, Brazil: International Osteoporosis Foundation; 2004. p. 7-8.

10. Ettinger MP. Aging bone and osteoporosis: strategies for preventing fractures in the elderly. Arch Intern Med 2003;163:2237-46.

11. Geusens P, Dequeker J, Gielen J, Schot LP. Non-linear increase in vertebral density induced by a synthetic steroid (Org OD 14) in women with established osteoporosis. Maturitas 1991;13:155-62.

12. Bjarnason NH, Bjarnason K, Haarbo J, Rosenquist C, Christiansen C. Tibolone: prevention of bone loss in late postmenopausal women. J Clin Endocrinol Metab 1996;81:2419-22.

13. Riggs BL. Tibolone as an alternative to estrogen for the prevention of postmenopausal osteoporosis in selected postmenopausal women. J Clin Endocrinol Metab 1996;81:2417-8. 
14. Kenemans P, Speroff L; International Tibolone Consensus Group. Tibolone: clinical recommendations and practical guidelines. A report of the International Tibolone Consensus Group. Maturitas 2005;51:21-8.

15. Hochberg MC, Greenspan S, Wasnich RD, Miller P, Thompson DE, Ross PD. Changes in bone density and turnover explain the reductions in incidence of nonvertebral fractures that occur during treatment with antiresorptive agents. J Clin Endocrinol Metab 2002;87:1586-92.

16. Physicians guide to prevention and treatment of osteoporosis. Washington DC: National Foundation; 1999. 